\title{
The eye-catching cicada Hamza ciliaris (Linnaeus, 1758) comb. $n$. in Indonesia and the Pacific: taxonomic status, synonymy, and distribution (Homoptera, Cicadoidea)
}

\author{
J.P. Duffels \\ Institute of Taxonomic Zoology (Zoological Museum), University of Amsterdam, Plantage Middenlaan \\ 64, 1018 DH Amsterdam, The Netherlands
}

Keywords: Hamza ciliaris, Cicadoidea, taxonomy, distribution, Indonesia, Pacific

\begin{abstract}
The new combination Hamza ciliaris (Linnaeus) is proposed for a cicada species widely distributed in Maluku (= Moluccas), Timor, Banda, Kei and Banggai Islands, the Philippines, and the Palau group of the Caroline Islands.

The synonymy of five species, treated in the literature as junior synonyms of Platypleura ciliaris, is confirmed and three other species are synonymized with Hamza ciliaris for the first time: Hamza bouruensis (Distant), H. uchiyamae Matsumura, and Platypleura lyricen Kirkaldy.

The redescription of Hamza ciliaris is followed by discussions on its distribution, habitat, and taxonomic position. The current classification of the genus Hamza in the separate tribe Hamzini is questioned by the results of this study. Some remarks are made on the classification of the cicadas in general.
\end{abstract}

\section{Résumé}

On propose la nouvelle combinaison Hamza ciliaris (Linnaeus) pour une espèce de Cigale à vaste distribution aux Moluques (Maluku), à Timor, à Banda, à Kei et aux îles Banggai, aux Philippines et au groupe Palau des Carolines.

On confirme la synonymie de cinq espèces considérées dans la littérature comme synonymes plus récents de Platypleura ciliaris, et trois autres espèces sont pour la première fois synonymisées avec Hamza ciliaris: Hamza bouruensis (Distant), H. uchiyamae Matsumura, et Platypleura lyricen Kirkaldy.

La redescription de Hamza ciliaris est suivie par une discussion concernant sa distribution, son habitat et sa position taxonomique. On met en question, en se basant sur les résultats de la présente étude, la classification actuelle du genre Hamza dans une tribu distincte, Hamzini. Quelques remarques sont faites sur la classification des Cigales en général.

\section{Introduction}

Hamza bouruensis (Distant, 1898) is one of the eyecatching cicadas in Indonesia. It was described as Platypleura bouruensis after a female from Buru Island. Following the discovery of the male, which appeared to have very peculiar tymbal coverings, Distant (1904) erected the genus Hamza to accommodate $P$. bouruensis. The only other species described in Hamza is $H$. uchiyamae Matsumura, 1927, recorded from the Palau group in the Pacific Caroline Islands. This species was also examined for the present study.

Study of the genus Hamza focussed my interest on the identity of two species of the genus Platypleura Amyot \& Serville, 1843: $P$. lyricen Kirkaldy, 1913, described from Ambon, and $P$. ciliaris (Linnaeus, 1758). $P$. ciliaris (and its synonyms) is recorded from a wide range of localities (Metcalf, 1963), but specifically from some of the Maluku Islands: Ambon, Ternate, Seram, and Morotai. Linnaeus' original description of Cicada ciliaris revealed that the species had been described from "Indiis" ( = former Dutch East Indies = Indonesia). Although Linnaeus discriminated between Indiis and India, Metcalf's catalogue (1963) mentioned India erroneously as type-locality.

My investigations show that Platypleura ciliaris (Linnaeus, 1758) is a senior synonym of $H$. bouruensis, $H$. uchiyamae, and Platypleura lyricen. $P$. ciliaris is hereby transferred to the genus 
Hamza. Earlier synonyms known from the literature have been checked for this study and the typematerial available has been examined.

\section{Depositories}

The material examined for this study comes from the institutions listed below; abbreviations are given as far as these are used in the text.

BMNH Natural History Museum (formerly: British Museum (Natural History)), London, United Kingdom

BPBM Bernice P. Bishop Museum, Honolulu, U.S.A.

CAS California Academy of Sciences, Department of Entomology, San Francisco, U.S.A.

KBIN Koninklijk Belgisch Instituut voor Natuurwetenschappen, Brussels, Belgium

MZB Museum Zoologicum Bogoriense, Bogor, Indonesia

MZS Musée Zoologique de l'Université Louis Pasteur et de la Ville Strassbourg, France

National Museum of Victoria, Melbourne, Australia

NMW National Museum of Wales, Cardiff, United Kingdom

RMNH National Museum of Natural History (formerly: Rijksmuseum van Natuurlijke Historie), Leiden, The Netherlands

University of Uppsala, Department of Entomology, Uppsala, Sweden

ZMA Institute of Taxonomic Zoology (Zoological Museum), Amsterdam, The Netherlands

Zoological Museum, University of Copenhagen, Denmark

\section{Genus Hamza Distant}

Hamza Distant, 1904: 674.

Type-species: Platypleura bouruensis Distant, 1898 (by original designation).

The genus Hamza was characterized by the peculiar, narrow tymbal coverings, leaving the medial parts of the tymbals exposed (Figs. 6-10), and was placed in a new division, Hamzaria Distant (1905). Most later authors followed Distant and placed the genus in the tribe Hamzini or the subtribe Hamzaria of the tribe Gaeanini Distant, 1905 (cf. Metcalf, 1963; Duffels \& Van der Laan, 1985). A discussion on the taxonomic position of Hamza and the tribe Hamzini is presented in a separate section: taxonomic discussion.
Hamza ciliaris (Linnaeus, 1758) comb. $n$.

(Figs. 1-16)

The following references give the original descriptions of the synonymous species and the literature used in establishing the identity of the species. A complete bibliography can be obtained from the catalogues of Metcalf $(1962,1963)$ and Duffels \& Van der Laan (1985).

Cicada ciliaris Linnaeus, 1758: 436; Linnaeus, 1767: 706; Metcalf, 1963: 54.

Cicada ocellata Degeer, 1773: 220, pl. 33 figs. 2-3.

Cicada varia Olivier, 1790: 756; Olivier, 1797: pl. 113 fig. 6; Guérin-Méneville, 1818: 39.

Tettigonia marmorata Fabricius, 1803: 38. Lectotype here designated.

Platypleura arcuata Walker, 1858: 1.

Platypleura catocaloides Walker, 1868: 82. Lectotype here designated.

Poecilopsaltria ciliaris; Distant, 1889: 16 (pl. 1 figs. 4, 4a-b do not depict Hamza ciliaris but an unidentified species of the genus Platypleura).

Platypleura bouruensis Distant, 1898: 97. Syn. n.

Hamza bouruensis; Distant, 1904: 674, pl. 30 figs. 5, 5a-b; Distant, 1914: 27, pl. 3 figs. 28, 28a-b.

Platypleura lyricen Kirkaldy, 1913: 7-8. Syn. n.

Hamza uchiyamae Matsumura, 1927: 47, pl. 2 fig. 3; Esaki, 1947: 29, pl. 1 fig. 1; Esaki \& Miyamoto, 1975: 633, 634, 647-649, figs. 8-9. Syn. $n$.

Platypleura ciliaris; Metcalf, 1963: 54.

\section{The identity of Cicada ciliaris}

The identity of Cicada ciliaris Linnaeus, 1758 described from "Indiis" was established through the courtesy of Mr. Sten Jonsson, Department of Entomology, University of Uppsala, who allowed me to study the type-specimen of this species from the collection of the former museum of Gustavus Adolphus, king of Sweden. The type-specimen (Fig. 1), which is regarded as the holotype of Cicada ciliaris, is a female with the label "ciliaris/typus" (ciliaris underlined). The holotype appeared to be identical with the cicada currently known as Hamza bouruensis.

In the 12th edition of his Systema Naturae (1767: 706) Linnaeus referred, under Cicada ciliaris, to Pl. 135 in Rumphius' Herbarium Amboinense (1743), which depicted a cicada named "Vero Cicadam 

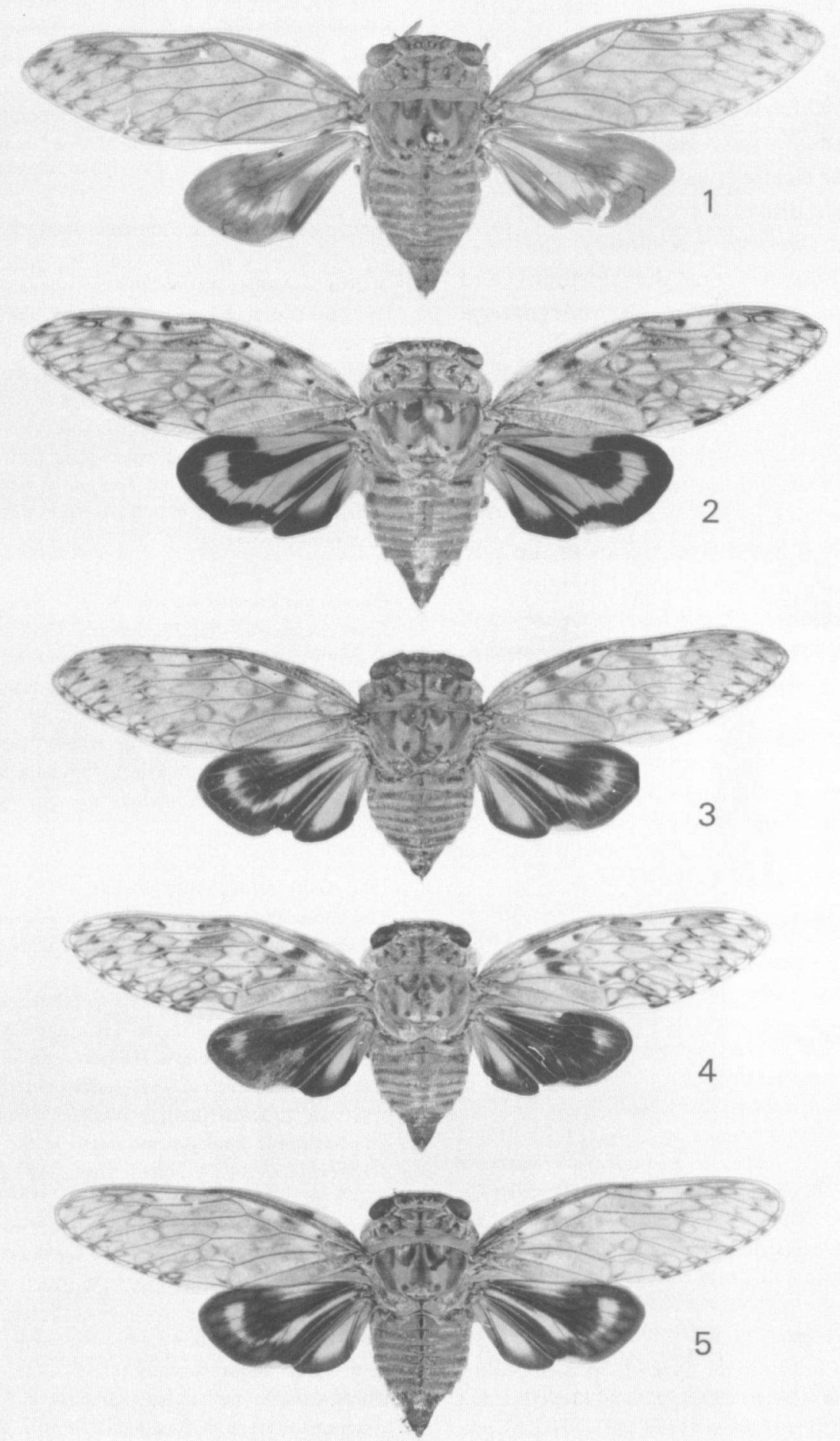

Figs. 1-5. Hamza ciliaris, $9: 1$, holotype of Cicada ciliaris Linnaeus; 2, specimen from northern central Seram, Manusela National Park; 3-4, from Buru, Doherty; 5, from Gebe Island. 
ipsam" in Latin or "De Krekel of Sprinkhaan zelfs" in Dutch. The cicada was very abundant in the forests of Ambon and gave its name to the tree, called "Cicadaria" in Latin and "De KrekelBoom" in Dutch, which is depicted on pl. cxxxv fig. A. The cicada on pl. cxxxv fig. B is not Cicada ciliaris but another cicada species. In spite of some incongruencies this drawing probably depicts the recently described Baeturia macgillavryi De Boer, 1989, which is known from the northern and southern Moluccas and Timor. B. macgillavryi seems to be a common species in Ambon (De Boer, 1989).

\section{Synonymic species of Hamza ciliaris}

Metcalf $(1962,1963)$ listed five species in the synonymy of Platypleura ciliaris, and I hereby add: Platypleura bouruensis, Platypleura lyricen, and Hamza uchiyamae. The synonymy of the species involved is discussed briefly.

\section{Cicada ocellata Degeer, 1773}

The type-locality of this species is unknown. Degeer's description agrees with Hamza ciliaris and his figures (pl. 33 figs. 2-3) certainly depict this species, so that the synonymy with Cicada ciliaris, as proposed (cf. Metcalf, 1963), is correct.

Cicada ocellata Fabricius, 1775 [nec Degeer] is a synonym of Flata stellaris (Walker, 1851) (cf. Metcalf, 1957; Medler, 1990), a species belonging to the family Flatidae of the superfamily Fulgoroidea and not to the Cicadoidea. Fabricius' later references $(1787,1794)$ to Cicada ocellata are incorrectly listed by Metcalf (1963) under Platypleura ciliaris, probably because Fabricius himself (1794) referred incorrectly to Cicada ocellata Degeer in his description of Cicada ocellata Fabricius.

The description of Cicada ocellata by Olivier (1790: 751) is copied from Degeer (1773), while some additional characters are taken from Caspar Stoll's description of "De Ruigvleugelige Cicade (La Cigale à Aîles Velues)" (Stoll, 1781: 39, pl. vii fig. 37) from the Cape of Good Hope, a species erroneously regarded by Olivier (1790) as identical to $C$. ocellata Degeer.

\section{Cicada varia Olivier, 1790}

This species was described from the Cape of Good Hope. The description of $C$. varia (Olivier, 1790: 756) and the figure that was published some years later (Olivier, 1797: pl. 113 fig. 6), perfectly fit Hamza ciliaris. In this description Olivier (1790) refers to the description and figure of "De Bruingeringde Zingende Cicade (La Cigale Chanteuse à Anneaux Brunes)" from the Cape of Good Hope by Caspar Stoll (Stoll, 1788: 102, pl. xxvi fig. 147). Stoll's coloured drawing is a good illustration of Hamza ciliaris. It seems that Olivier's figure of Cicada varia has been copied from Stoll, while the description was copied though restyled. Cicada varia was probably erroneously recorded from the Cape of Good Hope; since the shipping route between the Orient and Europe was via Cape of Good Hope, specimens collected in the Orient and Cape of Good Hope may have become mixed up.

Tettigonia marmorata Fabricius, 1803

The identity of this species could be established by the courtesy of Dr. N. Møller Andersen, Copenhagen, who allowed me to study the two male type-specimens (cf. Zimsen, 1964) in the collection of the Copenhagen Zoological Museum. One of these, labelled "marmorata", is designated lectotype of Tettigonia marmorata Fabricius, 1803. The other type-specimen has been labelled paralectotype. Study of these type-specimens proved the synonymy of Tettigonia marmorata and Hamza ciliaris. The type-locality Amboina, of Tettigonia marmorata, as given by Fabricius (1803: 38), is in agreement with the distribution of Hamza ciliaris.

\section{Platypleura arcuata Walker, 1858}

This species was described from "Ceram or Amboina". The description agrees with Hamza ciliaris. In the collection of the BMNH I found one specimen which I regard as the holotype of Platypleura arcuata, because it fits the description of Platypleura arcuata and bears the labels "Cer. ... Amb/Pfeiff" (handwritten), "68 4" (print), "arcuata Walk." (handwritten and underlined). Platypleura arcuata proved to be a junior synonym of Hamza ciliaris.

\section{Platypleura catocaloides Walker, 1868}

This species was described in the female sex only, from Amboina, Ceram, and Morty (= Morotai). The description agrees with Hamza ciliaris.

I have seen three alleged type-specimens of this species, one in the BMNH and two in the Melbourne Museum. The female type-specimen in the BMNH bears the labels "Amb." (round label; handwritten), "67/66" (handwritten), "Ceram/Wallace", ("Ceram" handwritten; "Wallace" printed), "catocalina" (handwritten). The type-specimens in the Melbourne Museum are labelled as follows: one female: “ $M$ "' (handwritten), "Wallace" (printed between two lines), "Platypleura/catocalina/ Morty" (Walker's handwriting); one female: "Amb." (handwritten), "Wallace" (printed between two black lines), "Platypleura/catocalina/Amboina" (Walker's handwriting). I have designated the London specimen as the lectotype, so that the two specimens from Melbourne become paralectotypes. The species name catocalina apparently refers to the moth genus Catocala which shows a similar band pattern on its wings, but Walker changed the name before publication in the perhaps more appropriate catocaloides.

The Melbourne collection also contains a male with similar labels as the two female paralectotypes in this collection: "M" (handwritten), "Morty/Wallace" ("Morty" handwrit- 

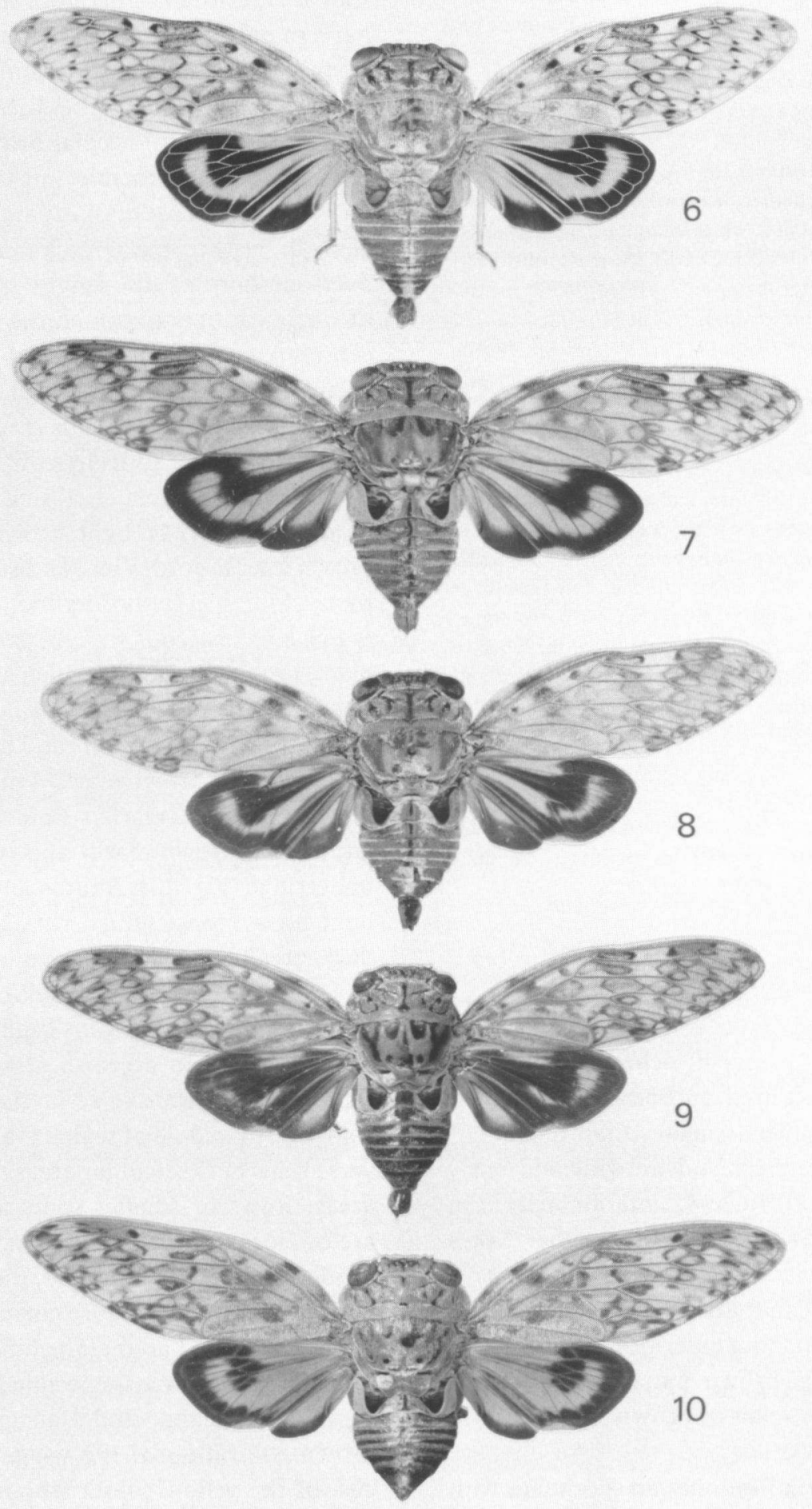

Figs. 6-10. Hamza ciliaris, o: 6, specimen from northern central Seram, Manusela National Park; 7, from Ternate, Van Lansberge; 8, from Ambon, F. Muir; 9, from Gebe Island; 10, from Koror Island, Palau group. 
ten; "Wallace" printed between two lines), "Platypleura/catocalina/Morty (Walker's handwriting). Though this male also belongs to the material collected by A.R. Wallace, it cannot be a type-specimen of Platypleura catocaloides, because the species has been described in the female sex only. The four specimens discussed above all belong to Hamza ciliaris.

Platypleura bouruensis Distant, 1898

This species was described after one female from Buru, now in the collection of the BMNH, which must be regarded as the holotype of this species. It bears the labels: "Buru/Fruhstorfer" ("Buru" handwritten; "Fruhstorfer" printed), "bouruensis/ Dist type" (Distant's handwriting), "Type" (printed on redmargined label), "Distant Coll./1911-383" (print). The description agrees with Hamza ciliaris, and the holotype belongs to this species.

Platypleura lyricen Kirkaldy, 1913

This species was described after three males and six females from Amboina; the type-specimens are in the collection of the Bishop Museum, Honolulu. Study of the type-specimens proved the synonymy of this species with Hamza ciliaris. One male bears two labels: "Platypleura/lyricen/Kirk/No. 630/Holotype" (Holotype printed in red-coloured right margin of the label; remaining text handwritten), and "Amboina/F. Muir" (handwritten). The other specimens of the type series bear a yellow "Paratype" label.

Hamza uchiyamae Matsumura, 1927

My study of a large series of Hamza uchiyamae from the Palau group of the Caroline Islands proved this species to be a junior synonym of Hamza ciliaris.

\section{Description}

Body brownish to greenish ochraceous. Males somewhat darker coloured on body and tegmina, and on average somewhat smaller than females.

Head: Postclypeus greenish with wide and fairly deep, median, ventral, furrow; anterior margin in dorsal view with brown coloration of either 2 or 3 narrow parallel fasciae, or one broad fascia or a median mark. Median part of vertex dark redbrown to dark brown from anterior margin to level of paired ocelli; this brown patch often extends laterad toward eyes. A pair of brown spots at lower inner margins of eyes.

Thorax: Pronotum of Indonesian specimens with medial brown line usually extending from anterior pronotal margin to collar but occasionally interrupted; Palau specimens with short narrow line on anterior half of pronotum and a median transverse spot at anterior margin of pronotal collar. Anterior parts of anterior oblique fissures, posterior oblique fissures, and lateral parts of ambient fissure brown. A pair of brown spots between both pairs of fissures. Mesonotum: Medial brown fascia very narrow or hardly discernible anteriorly, and very wide on posterior half of disc. A pair of paramedian, obconical, brown marks at anterior margin extend over one-third of disc length; mediodistal margins of obconical marks sometimes darker brown than central parts. A pair of round brown spots in front of anterior angles of cruciform elevation. A pair of sublateral, triangular fields reaching from anterior margin to level of spots in front of cruciform elevation. These triangular fields either uniformly light or dark brown, or light brown with broad dark brown lateral borderline, and sometimes with dark parts along medial borderline.

Legs: Ochraceous to light brown with brown to black-brown marking, which is very faint in the specimens from Palau. Fore coxae ventrally with apical brown spot, middle and hind coxae with ventral triangular brown mark. Trochanter of fore legs with some dark marks. Fore femora with fairly large black brown marks and two broad spines on underridge (Fig. 13). Middle and hind femora with light brown longitudinal streaks. Fore tibiae with dark streaks and black-brown toward apices. Tarsi of fore and middle legs black-brown.

Tegmina and wings: Tegmina opaque with brownish grey to greenish grey spots arranged in three irregular transverse fasciae: one along corial fold, one in middle of tegmen, and one along transverse veins between ulnar areas and 1st to 5th apical areas. Rows of smaller spots are found in apical areas, close to ambient vein and in hyaline tegmen border. Wings: Yellow to orange-yellow with a dark brown angular figure narrowing to wing basis, and dark brown bands along hind margin and along brachial vein. In most specimens from Buru (Figs. 3-4), Sula Island, and Banggai Archipelago the brown coloration of the wings is extended at the cost of the yellow colour, though some specimens have a wing pattern identical to those of the more eastern islands. Such conspicuous extension of brown wing coloration is also found in one speci- 


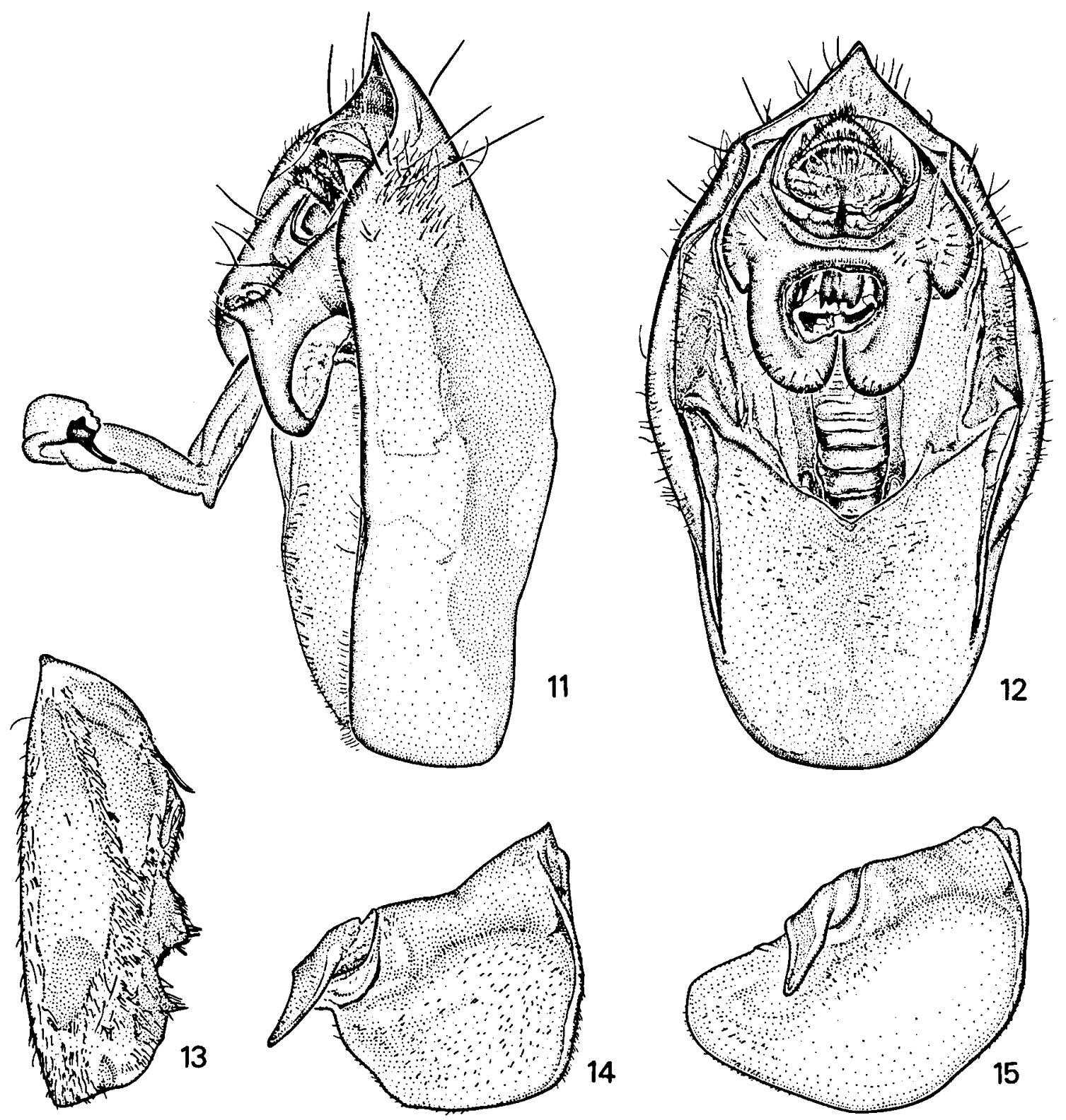

Figs. 11-15. Hamza ciliaris: 11, ơ pygofer in lateral view, endophallus extended, northern central Seram, Manusela National Park; 12, $\sigma$ pygofer in ventral view, Ambon, F. Muir; 13, femur of left fore leg in lateral view, northern central Seram, Manusela National Park; 14, $\odot$ operculum and meracanthus, northern central Seram, Manusela National Park; 15, $\sigma^{\circ}$ operculum and meracanthus in ventrolateral view, Seram, coll. Camille van Voixem.

men from Gebe Island (Figs. 5, 9) and to a lesser extent in material from other islands.

Male: Operculum (Fig. 15) ochraceous, reaching anterior margin of abdominal segment 3. Lateral, apical, and medial margins convex. Abdomen light brown with silver pilosity. Tymbal covering ochraceous, covering lateral part of tymbal cavity only. Dorsal sides of segments 3-7 with dark brown transverse fasciae along anterior margins of segments, and reaching to about two thirds of segment lengths. The fasciae are usually interrupted medial- 
ly, where many specimens have a light brown, median spot reaching from anterior to posterior segment margins. Segment 8 dark brown.

Genitalia (Figs. 11-12): Pygofer in ventral view (Fig. 12) about twice as long as wide, widest at halflength. Caudodorsal beak broad, triangular and pointed (Figs. 11-12). Lateral margin in lateral view with fairly strongly developed shoulder. Cup of pygofer fairly wide. Uncus (abdominal segment 10) with two broad, apically broadly rounded, lobes enclosing the aedeagus and provided with a rounded lateral lobe (Fig. 12). Aedeagus long and broad, endophallus with sclerotized apical hook (Fig. 11).

Female: Operculum (Fig. 14) ochraceous, reaching to half-length abdominal segment 3. Lateral margin very weakly convex, laterodistal angle broadly rounded, apical and medial margins convex. Abdomen with dorsal, dark brown, transverse fasciae on segments 2-7 as described for the male; segments 8 and 9 dark brown dorsally.

Measurements $\left(10 \sigma^{\circ} \sigma^{\prime}, 10\right.$ \% $\left.\%\right)$. Body length $\sigma^{\circ}: 19.2-21.5 \mathrm{~mm}$ (20.3 \pm 0.7$)$, $\%: 19.7-23.8 \mathrm{~mm}(21.6 \pm 1.2)$; head width $\sigma$ : 8.6-9.3 mm (8.9 \pm 0.2$)$, $:$ : $8.8-10.1 \mathrm{~mm}(9.4 \pm 0.4)$; pronotum width $\sigma:$ : 9.8-10.8 $\mathrm{mm}(10.2 \pm 0.4)$, ९: $10.4-12.3 \mathrm{~mm}$ (11.1 \pm 0.6$)$; tegmen length $\sigma^{\circ}: 25.1-28.0 \mathrm{~mm}(26.5 \pm 1.0)$, ९ : $27.8-31.5 \mathrm{~mm}(29.0 \pm 1.2)$.

Exuviae: For a description of exuviae the reader is referred to the publication of Esaki \& Miyamoto (1975).

Geographic variation: The populations from the Palau group of the Caroline Islands and from Buru, Sula Island, and Banggai differ in several features from those of the other islands. Most, but not all, specimens from Buru, Sula, and Banggai have darker brown hind wrings (Figs. 3-4) than those from the more eastern islands of Indonesia and the West Pacific Islands. Most Palau specimens (Fig. 10) differ from the Indonesian specimens in a somewhat greenish tinge of body and tegmen, a more distinctly marked vertex, a very short medial pronotal fascia, more uniformly coloured paramedian and sublateral mesonotal fields and a weaker developed marking of the legs.

\section{Material examined}

Apart from the type-specimen of Cicada ciliaris and the material mentioned in the section on synonymic species, the following specimens have been studied (all data are directly taken from the museum labels):

Timor: Timor, coll. Macklot, 1 ९, RMNH.

Kei Islands: Kei, Latuhalat, 20.iv.1932, $3 \sigma \sigma 2$ \& \&, MZB.

Banda Island: Banda, coll. A. Koller, 1 \&, KBIN.

Southern Maluku: Seram: Ceram, coll. Camille van Voixem, Poecilopsaltria catocaloides Walk., Platypleura sp., Platypleura ciliaris, $1 \sigma$, KBIN; Ceram, Platypleura arcuata Wlk, $1 \sigma$, MZS; Ruhuwa, 3.v.1970, R.F. Ellen, Brit. Mus. 1972-53, 1 ᄋ, BMNH; Manusela N.P., Wae Mual Plain, 25.vii-2.ix.1987, Operation Raleigh, coll. M.J.D. Brendell, Brit. Mus. 1987-262, 2 ơ 5 \% \&, BMNH; Solea, Base Camp, riverside, $50 \mathrm{~m}$, viii-ix.1987, site 1, Operation Raleigh, J.D. Holloway et al., 1 १, BMNH; $3 \mathrm{~km} \mathrm{~N}$. of Solea, Lama, riverside, $70 \mathrm{~m}$, viii-ix.1987, site 3, Operation Raleigh, J.D. Holloway et al., 1 \%, BMNH.

Ambon: Amboina, A. Koller, $1 \sigma^{\circ}, \mathrm{KBIN}$; Amboina, 783, Vyane vend., Platypleura ciliaris L., 1 \&, KBIN; Amboina, Leitimor, Exp. Martin, xii.1891, Brit. Mus. 1962-168, 3 ९ , BMNH; same data but with: Poecilopsaltria ciliaris L., 1 \&, BMNH; Amboina, Hoedt, 1 \%, RMNH; Ambon, Hoedt, acq. 1865, 2 o $\sigma^{\circ} 1$ \%, RMNH; Amboina, D.S. Hoedt, 1866, $1 \sigma$, RMNH; Amboina, Mevr. H.K. Willemse Geeroms, $1 \sigma^{\circ}$, RMNH; Amboina, 1873, O. Beccari, Distant coll., Brit. Mus. 1912-383, 1 ९, BMNH; Amboyna, 1 ९, BMNH; Amboina, 1 १, BMNH; Amboina, R.H.F. Rippon coll. N.M.W. 1918.93, 1 \&, NMW; Amboina, macklotti Herkl., 1 \&, RMNH; Amboina, Forsten, 1 \&, RMNH; Amboina, F. Muir, $1 \sigma$, BPBM; Amboina, x. 1907, F. Muir, 2 ơ 01 \&, BPBM; same data but iv. 1908, $1 \sigma^{\circ}$, BPBM; Ambon I., Waai, 30.viii.1963, A.M.R. Wegner, 1 o 1 \&, BPBM; same data but 3.x.1963, $1 \circ 7$ ८ १, 4.x.1963, 5 ơ ơ 2 ९ , 30.x.1963, 1 ९, 23.i.1964, 1 १, 26.iv.1964, 1 ९, 9.viii.1964, 1 o, 21.x.1964, 1 ९, 8.xi.1964, 2 o 1 1 , all BPBM.

Buru: Buru, Distant coll., Brit. Mus. 1911-383, $1 \propto \sigma$, BMNH; Boeroe, Hoedt, acq. 1863, 3 \& \&, RMNH; same data but with Hamza bouruensis Dist., det. H.C. Blote, 1 \&, RMNH; Bouru, Doherty, Distant coll., Brit. Mus. 1911-383, 4 ९ \&, BMNH; Buru, W. Doherty, Brit. Mus. 1903-31, 1 ९, BMNH; Bouru, R.H.P. Rippon coll., N.M.W. 1918.93, 3 ९ ९, NMW; W. Bouru, Bara, ix, Brit. Mus. 99-197, 2 ९ ९, BMNH; Boeroe, Poecilopsaltria basi-viridis Walk. var.?, det MacGillavry, coll. Dr. D. Mac Gillavry, 1 o, ZMA; Buru, station 1, 1921, 1 ९, ZMA.

Saparua: Sapurua, 1 ९, MZS; Saparoen, 4 ơ 06 ९ , KBIN; Saparoea, Oeliasers, Exp. Martin, i.1892, Poecilopsaltria ciliaris L., 1 \% , BMNH; Saparoea, Platypleura ciliaris L., 1 \&, MZS.

Sula Islands: Taliaboe, J.W. v. Nouhuys, 2 १ , RMNH. Banggai Islands: Potil Kecil, $1^{\circ} 28^{\prime} \mathrm{S} 123^{\circ} 34^{\prime} \mathrm{E}, 12-19$.ii.1980, M.J.D. Brendell, at light, Brit. Mus. 1980-280, 3 o o 2 ९ ९, BMNH. 
Northern Maluku: Ternate: Ternate, W. Doherty, Brit. Mus. 1903-31, 4 \& \&, BMNH; Ternate, v. Lansberge, $1 \sigma^{\circ}, \mathrm{RMNH}$. Morotai: Morotai, Bernstein, 1 ○ 2 \& \&, RMNH; Morty Island, Distant coll., Brit. Mus. 1911-383, 1 \&, BMNH.

Gebe Island: Geby Island, Distant coll., Brit. Mus. 1911-383, $1 \circ 2$ \% \&, BMNH.

Caroline Islands, Palau Group: Babelthuap Island: Ngeremlengui, 4.iv.1957, C.W. Sabrosky, at light, 1 \% , BPBM; same data but 3.iv.1957, 1 ○ , BPBM; Ngeremlengui, Armaten, 28.iv.1936, Z. Ono, 1 \% , BPBM; Ngiwal, 19.v.1957, C.W. Sabrosky, at light, 1 \&, BPBM; same data but 20.v.1957, 1 \& , BPBM.

Koror Island: 14.xi.1963, F.A. Bianchi, light trap, $1 \sigma^{\circ}$, BPBM; same data but 1-15.xii.1963, 3 o o 2 \& \&, BPBM; 1.iv.1957, C.W. Sabrosky, 2 ơ ơ 1 ९, BPBM; same data but 27.v.1957, at light, 1 ơ 2 \& $\%$, BPBM.

Urukthapel Island: Garamejo, 27.viii.1949, A.R. Mead, 2 o $\sigma$ 1 \&, BPBM.

Peleliu Island: 21.iv.1936, Y. Kondo, $3 \sigma \sigma 2$ ९ १, BPBM; 20.iv.1936, Z. Ono, 1 \% , BPBM; 23.iv.1936, Z. Ono, $2 \sigma^{\circ} \sigma^{\circ}$, BPBM; near X-roads, 23.iv.1936, Z. Ono, $2 \circ \sigma$, BPBM; without date, Z. Ono, 3 o $\sigma^{\circ} 1$ \&, BPBM; N. end Peleliu, 28.v.1957, C.W. Sabrosky, at light, 2 ○ $\% 2$ ९ १, BPBM; Peleliu I., north central Pelew Islands, 12.viii.1945, H.S. Ducoff, at light, 1 \%, BPBM.

Angaur Island: 16.iv.1936, Y. Kondo, Platypleura uchiyamae, $1 \circ$, BPBM; same data but $17 . i v .1936$ and without identification label, $1 \circ$, BPBM.

Palau Islands: Kokok, 15.iii.1948, Hamza uchiyamae, $1 \sigma^{\circ}$ CAS; Ngerkatasang I., 13.v.1957, C.W. Sabrosky, 1 \& , BPBM; Ogiwal, 10.iv.1936, Z. Ono, 3 ơ ơ 1 \&, BPBM; Palao Ils, 30.iv.1936, Z. Ono, $1 \sigma$, BPBM.

Philippines: Philippine Is., J.J. Mounsey, Brit. Mus. 1912-181, 581,1 ९, BMNH; same data but 582, 1 \&, BMNH.

\section{Distribution}

Hamza ciliaris is recorded from Timor, Kai Island, Banda Island, the southern Maluku Islands, the Banggai and Sula Archipelagoes, the northern Maluku Islands with records from Ternate, Morotai and Gebe, Mindanao in the Philippines, and the Palau group of the Caroline Islands (Fig. 16). The record from Timor is based upon one specimen without specified locality. The records from the Philippines are based upon one or two specimens without specified locality and two females of Hamza sp. from Davao and Mt. Apo in Mindanao mentioned by Endo \& Hayashi (1979). Specimens labelled Sumatra and Queensland, in the $\mathrm{BMNH}$ collection, are regarded as mislabelled.

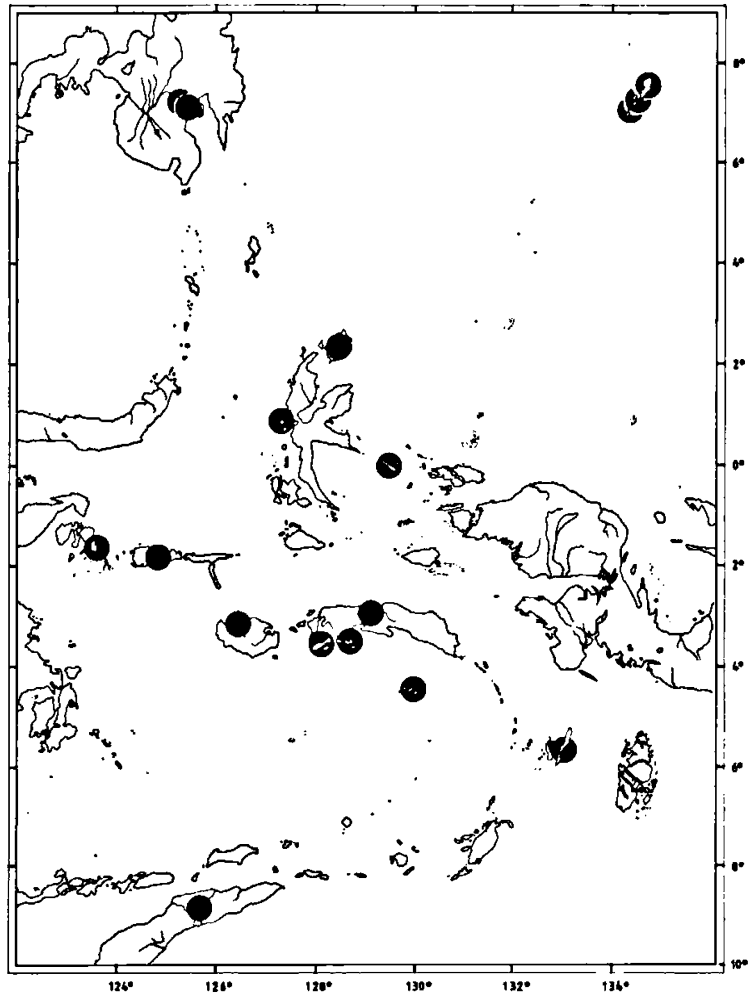

Fig. 16. Distribution of Hamza ciliaris.

The interesting wide distribution of Hamza ciliaris from Timor to Mindanao and the Palau Islands and its supposed absence in Sulawesi and New Guinea resembles the distribution of Baeturia macgillavryi, which is found in Timor, southern and northern Maluku, and the Talaud Islands (De Boer, 1989).

\section{Habitat}

$H$. ciliaris seems to be a common species in all of the Palau Islands, where the adults occur all year round (Esaki \& Miyamoto, 1975). The species has been found on deciduous trees and palms and even on lower plants (Esaki, 1936).

The Raleigh Expedition of 1987 in Seram made a light-trapping transect for collecting moths and other insects from $50 \mathrm{~m}$ to $2800 \mathrm{~m}$. Six cicada species were collected at altitudes from $50 \mathrm{~m}$ to $1000 \mathrm{~m}$; the song of cicada ceased just below $2000 \mathrm{~m}$ (J.D. 
Holloway, pers. comm.). Hamza ciliaris was collected at $50 \mathrm{~m}$ and $70 \mathrm{~m}$.

These data and the information on the labels of the museum specimens suggest that $H$. ciliaris is probably a species of lower altitude.

\section{Taxonomic discussion}

The relationships of Hamza ciliaris

While investigating the taxonomic position of Hamza ciliaris my attention was drawn to Platypleura hilpa (Walker, 1850), recorded from southern China, Hainan, Hong Kong, and Taiwan (cf. Metcalf, 1963; Duffels \& van der Laan, 1985; Hill, 1982). This species, apart from its fully developed tymbal coverings, closely resembles $H$. ciliaris, especially in colour and pattern on tegmina and wings (see for habitus of $P$. hilpa: the drawing in Distant, 1889: pl. 1, fig. 6 and the colour photograph in Hill, 1982: 20, fig. 6). Some very similar structures in pygofer and uncus of the male genitalia of $H$. ciliaris and $P$. hilpa suggest a close relationship between these species.

A comparison of the two species with the descriptions of African Platypleurini by Boulard (1972, 1973) revealed that the two species share several external and genitalic features that are regarded characteristic of the African genus Soudaniella Boulard, 1973. This genus was described together with six other new genera, and in connection with a new classification of the African representatives of Platypleura (Boulard, 1972, 1973). Boulard's studies will be taken as a guide for a planned revision of the Oriental Platypleura species including Hamza ciliaris.

\section{The status of the Hamzini questioned}

Distant's division Hamzaria contained only the genus Hamza, until the monotypic African genus Tugelana Distant, 1912 was included (Distant, 1914). In this publication Distant (1914) already indicated that this division could, apart from the narrow tymbal coverings, be easily confused with
Platypleura. Kato $(1932,1956)$ did not accept the Hamzaria as a separate group and placed the genus Hamza in the tribe Platypleurini Schmidt, 1918, because of resemblance in the body shape, especially the dilated sides of the pronotum (cf. discussion in: Esaki \& Miyamoto, 1975). Schmidt (1926) and recently Esaki \& Miyamoto (1975) classified Hamza in a separate tribe Hamzini, mainly because the genitalic structure of Hamza does not show immediate relationship to that of Platypleura. In their opinion the tribe Hamzini may be a more primitive group. Hayashi (1978) considered Hamza allied to the Platypleurini. This opinion is confirmed by the present study, questioning the desirability of a separate tribe Hamzini.

Some remarks must be made on the taxonomic position of two other genera attributed to the subtribe Hamzaria by Metcalf (1963). In fact, Metcalf made an error by classifying Formotosena Kato, 1925 and Becquartina Kato, 1940 in the subtribe Hamzaria. In the literature compiled for Metcalf's catalogue Formotosena was attributed to the tribe Gaeanini (e.g. Kato, 1925, 1932), but not to the subtribe Hamzaria of the Gaeanini. In spite of its position in the Gaeanini, Kato (1925) regarded the genus closely allied to Tosena Amyot \& Serville, 1843 , though it differs in the rudimentary tymbal coverings. According to Hayashi (1978), Formotosena should be classified in the Polyneurini Amyot \& Serville, 1843, though the genus is similar to Tosena in colouration and body shape; the genus Tosena is currently attributed to the subtribe Tosenaria Amyot \& Serville, 1843 of the Dundubiini Atkinson, 1886. Becquartina, the other genus erroneously attributed to the Hamzaria by Metcalf (1963), should be placed in the Gaeanini, but not in the Hamzaria, since it is related to the genus Gaeana Amyot \& Serville, 1843 (cf. Kato, 1940) and not to Hamza.

The close relationship of the Platypleurini and the Hamzini invites general criticism on the classification of the family Cicadidae. Metcalf (1963) classified the Platypleurini in the subfamily Tibiceninae and the Hamzaria in the subfamily Gaeaninae (= Cicadinae, cf. Duffels \& Van der Laan, 1985: xiii), as a subtribe of the Gaeanini Distant, 1905. The attribution of these closely related tribes to two dif- 
ferent subfamilies follows from the subdivision of the family Cicadidae on account of the development of the tymbal coverings which partly (Cicadinae) or entirely (Tibiceninae) cover the tymbal cavities. This has resulted in an unsatisfactory classification of related genera of the Cicadidae in different subfamilies. This point of view has been expressed earlier by Wagner $(1960,1964)$, who considered the development of tymbal coverings one of the anagenetic trends found independently in various clade groups of cicadas. Hamza ciliaris and Platypleura hilpa are depicted by Wagner (1960: pl. VI) as examples of such a trend.

\section{Acknowledgements}

For the loan of material I am indebted to Dr. M. Amir, Bogor; Dr. P. Arnaud, San Francisco; Mr. S. Jonsson, Uppsala; Mr. A.H. Kirk Spriggs, Cardiff; Dr. W.J. Knight and Mr. M.D. Webb, London; Dr. J . Matter, Strassbourg; Mr. J. van Tol, Leiden; Dr. N. Møller Andersen, Copenhagen; Mr. G.M. Nishi$\mathrm{da}$ and Mr. K. Arakaki, Honolulu, and Dr. J. van Stalle, Brussels. I am very grateful to Mr. A.J. de Boer (Amsterdam) and Dr. M.R. Wilson (London) for critical reading of earlier drafts of this paper, to Mr. D.A. Langerak for the preparation of the drawings, to Mr. L.A. van der Laan for making the photographs, to Mrs. A. Stoel for typing, and to Mr. G. Verlaan for technical assistance.

\section{References}

Boer, A.J. de, 1989. The taxonomy and biogeography of the bloetei group of the genus Baeturia Stal, 1866 (Homoptera, Tibicinidae). Beaufortia, 39(1): 1-43.

Boulard, M., 1972. Contribution à l'étude de la faune cicadéenne de l'Angola (Insecta-Auchenorhyncha). Publções cult. Co. Diam. Angola, 84: 151-178.

Boulard, M., 1973. Classification raisonnée des Platypleures africaines (Homoptera-Cicadidae). Bull. Mus. natn. Hist. nat. Paris, (3) “1972” (90): 1161-1188.

Degeer, C., 1773. Mémoires pour servir à l'histoire des Insectes, 3: 1-696, pls. 1-44 (P. Hesselberg, Stockholm).

Distant, W.L., 1889. A monograph of Oriental Cicadidae, 1: 1-24, pls. 1-2 (West, Newman \& Co., London).

Distant, W.L., 1898. Description of two new species of Oriental Cicadidae. Ann. Mag. nat. Hist., (7) 1: 97.

Distant, W.L., 1904. Additions to a knowledge of the family Cicadidae. Trans. ent. Soc. London, 1904: 667-676, pls. 29 \& 30 .

Distant, W.L., 1905. Rhynchotal notes. XXXI. Ann. Mag. nat. Hist., (7) 15: 379-387.
Distant, W.L., 1914. Homoptera, Fam. Cicadidae, subfam. Gaeaninae. Genera Insect., 158: 1-38, pls. 1-3.

Duffels, J.P. \& P.A. van der Laan, 1985. Catalogue of the Cicadoidea (Homoptera, Auchenorhyncha) 1956-1980. Series Ent., 34: i-xiv, 1-414.

Endo, T. \& M. Hayashi, 1979. A note on Cicadidae collected and observed by $\mathrm{T}$. Endo in the Philippines. Cicada, 1: 35-38.

Esaki, T., 1936. Die Cicadiden-Fauna der Karolinen. Tenthredo, 1: 1-8, pls. 1-2.

Esaki, T., 1947. Hemiptera Micronesica, II. Cicadidae. Mushi, 17(7): 29-37, pl. 1.

Esaki, T. \& S. Miyamoto, 1975. Insects of Micronesia, Homoptera: Cicadidae. Insects Micronesia, 6(9): 633-656.

Fabricius, J.C., 1787. Mantissa Insectorum, sistens eorum species nuper detectas; adjectis synonymis, observationibus, descriptionibus, emendationibus, 2: 1-382 (C.G. Proft, Hafniae).

Fabricius, J.C., 1794. Entomologia systematica emendata et aucta, secundum classes, ordines, genera, species, adjectis synonymis, locis, observationibus, descriptionibus, 4: 1-472 (C.G. Proft, Hafniae).

Fabricius, J.C., 1803. Systema Rhyngotorum secundum ordines, genera, species adjectis synonymis, locis, observationibus, descriptionibus: i-x, 1-315 (C. Reichard, Brunsvigae).

[Guérin-Méneville, F.E.], 1818. Tableau encyclopédique et méthodique des trois règnes de la nature, 24. Crustacés, Arachnides et Insectes, par M. Latreille: [i-iv], 1-142 (Veuve Agasse, Paris).

Hayashi, M., 1978. The Cicadidae (Homoptera, Auchenorrhyncha) from East and Central Nepal (Part 2). Bull. natn. Sci. Mus. Tokyo, A (Zool.) 4(4): 267-279.

Hill, D.S., 1982. Hong Kong insects, 2: 1-144 (Urban Council, Hongkong).

Kato, M., 1925. The Japanese Cicadidae, with descriptions of some new species and genera. Trans. nat. Hist. Soc. Formosa, 15: 55-76, pls. 1-2.

Kato, M., 1932. Monograph of Cicadidae: 1-450, pls. 1-32 (Sanseido, Tokyo).

Kato, M., 1940. Description of a new genus with supplementary notes on Chinese Cicadidae in Musée Heude collection (Homoptera: Cicadidae). Notes Ent. chin., 7: 203-204.

Kato, M., 1956. The biology of cicadas. Bulletin Cicadidae Museum: 1-319, pls. 1-46 (Iwasaki Shoten, Jinbocho Kanda, Tokyo).

Kirkaldy, G.W., 1913. On some new species of leaf-hoppers. Part 1. Bull. Hawaiian Sug. Plrs' Ass. Exp. Stn., 12: 7-27.

Linnaeus, C., 1758. Systema naturae per regna tria naturae, secundum classes, ordines, genera, species, cum characteribus, differentiis, synonymis, locis (ed. 10), 1: [i-iv], 1-824 (Laurentii Salvii, Holmiae).

Linnaeus, C., 1767. Systema naturae per regna tria naturae, secundum classes, ordines, genera, species, cum characteribus, differentiis, synonymis, locis (ed. 12), 1(2): [i-ii], 533-1327, [1-37] (Laurentii Salvii, Holmiae).

Matsumura, S., 1927. New species of Cicadidae from the 
Japanese Empire. Insecta Matsumurana, 2: 46-58, pl. 2. Medler, J.T., 1990. Types of Flatidae (Homoptera) XIV. Walker and Distant types in the British Museum. Orient. Insects, 24: 127-195.

Metcalf, Z.P., 1957. Fulgoroidea, Flatidae and Hypochthonellidae. General catalogue of the Homoptera, 4(13): i-viii, 1-565 (North Carolina State College, Raleigh, N.C.).

Metcalf, Z.P., 1962. A bibliography of the Cicadoidea (Homoptera, Auchenorhyncha). General catalogue of the Homoptera, 8: i-iv, 1-229 (North Carolina State College, Raleigh, N.C.).

Metcalf, Z.P., 1963. Cicadoidea. General catalogue of the Homoptera, 8(1): i-vii, 1-585, 586-919 (North Carolina State College, Raleigh, N.C.).

Olivier, [G.A.], 1790. Encyclopédie méthodique. Histoire naturelle. Insectes, 5: 1-793 (Panckoucke, Paris).

[Olivier, G.A.], 1797. Tableau encyclopédique et méthodique des trois règnes de la nature, 18. Insectes: pls. 1-268 (H. Agasse, Paris). [These plates were engraved under the supervision of J.P. Bonnaterre; the explanation to them was furnished by F.E. Guérin-Méneville in 1818.]

Rumphius, G.E., 1743. Herbarium amboinense, plurimas conplectens arbores, frutices, herbas, plantas terrestres \& aquaticas, quae in Amboina, et adjacentibus reperiuntur insulis, adcuratissime descriptas juxta earum formas, cum diversis denominationibus, cultura, usu, ac virtutibus, quod \& insuper exhibet varia insectorum animaliumque genera, ... cura \& studio Joannis Burmanni ..., 3: [i-ii], 1-218, pls. I-CXLI (F. Changuion et al., Amstelaedami; P. Gosse et al., Hagae
Comitis; S. Neaulme, Ultrajecti).

Schmidt, E., 1926. Fauna Buruana. Homoptera. Treubia, 7: 217-258.

Stoll. C., 1781. Natuurlijke en naar 't leeven naauwkeurig gekleurde afbeeldingen en beschrijvingen der cicaden in alle vier waerelds deelen Europa, Asia, Africa en America huishoudende, bij een verzameld en beschreeven door Caspar Stoll, 4: 37-43, pls. VII-VIII (Jan Christiaan Sepp, Amsterdam).

Stoll, C., 1788. Idem, 11: 93-116, pls. XXV-XXVIII.

Wagner, W., 1960. Probleme bei der Aufstellung eines phylogenetischen Systems. Abh. Verh. naturw. Ver. Hamburg, (N.F.) 4: 109-128, pl. VI.

Wagner, W., 1964. Individuelle Variation und Anagenese als Phänomene des Wachstums. Mitt. hamb. zool. Mus. Inst., 61 (Suppl.): 293-314, pl. XII.

Walker, F., 1858. Insecta Saundersiana: or characters of undescribed insects in the collection of William Wilson Saunders, Esq., F.R.S., F.L.S., \& c. Homoptera: 1-117 (John van Voorst, London).

Walker, F., 1868. Catalogue of the homopterous insects collected in the Indian Archipelago by Mr. A.R. Wallace, with descriptions of new species. J. Linn. Soc. Lond. (Zool.), 10: 82-193, pl. 3.

Zimsen, E., 1964. The type material of I.C. Fabricius: 1-656 (Munksgaard, Copenhagen).

Received: 12 February 1991 